\title{
Aquatic resources critical to California's productivity, quality of life
}

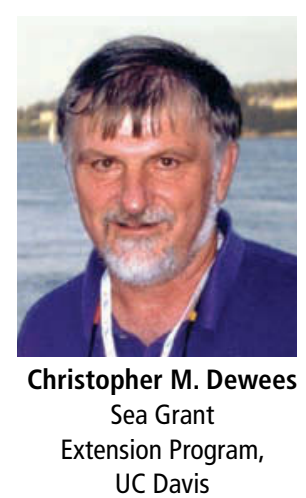

$\mathrm{N}$ utrient-rich waters make California's coastal ocean one of the most productive in the world. However, California's rapid population growth from 20 million to 35 million since 1970 is increasingly stressing these and other finite aquatic resources. What were once considered boundless resources are now in danger.

Before the arrival of Europeans, Native Americans harvested an estimated 8.5 million pounds of salmon yearly from Central Valley streams. After statehood, the ability to collect, store and deliver fresh water was critical to the growth of California's premiere agricultural industry as well as its urban centers and suburban communities.

Commercial fisheries developed rapidly at first, but sometimes plummeted later due to environmental or fishing pressures. In 1882, 12 million pounds of salmon were harvested from the San Francisco Bay-Delta for canning. The canneries closed by 1919 and the fishery moved onto ocean waters as statewide landings declined to less than 5 million pounds in recent years. From the 1920s to 1940s, the Pacific Coast sardine fishery was the largest fishery in the Western Hemisphere, with up to 700,000 tons landed annually. The fishery declined rapidly during the 1950s due to a combination of cyclic changes in the ocean environment and heavy fishing. Ocean conditions more favorable to sardine populations over the past 20 years have led to recovery of the sardine resource and rebirth of the fishery.

As California's population grows, stresses on our aquatic and ocean resources intensify. Many Californians are aware of these cases in point:

- Battles over complex water allocation issues persist in the Klamath Basin, San Francisco Bay-Delta and Salton Sea. High-quality water is in demand for irrigation, drinking, industry, wildlife and fish.

- Along the coastal zone, where over $75 \%$ of our population lives, beaches are often posted or closed to swimming due to unhealthy water quality, affecting the state's multibillion-dollar coastal tourism industry.

- Large sections of our coastal waters are closed to fishing for species such as rockfish and abalone due to large declines in their abundance. Rebuilding these populations will take decades.

- Introductions of nonnative aquatic nuisance species are altering estuary ecosystems significantly (see page 102). A major source of introduced species is ballast water from ships, which deliver approximately $30 \%$ of the nation's imports through California ports. It will be difficult to find feasible solutions for this problem.

- The majority of the spawning habitat for salmon and steelhead was lost during the 20th century. This is only partially mitigated by hatchery production and habitat restoration efforts. Some salmon stocks have been listed under the Endangered Species Act, which has heightened conflicts over fish habitat and water.

Today the UC Division of Agriculture and Natural Resources (ANR) is well positioned to play a major role in addressing California's aquatic resource issues. Solutions to these complex problems should integrate the human resources, natural resources and agricultural sciences expertise available within ANR.

When I was hired as the Extension Marine Resources Specialist in 1972, I felt like a "fish out of water." Most of my UC Cooperative Extension (UCCE) colleagues were focused on production agriculture, home economics and $4-\mathrm{H}$ youth education. While some faculty were involved in aquatic and marine research, most academic departments working on wildlife, fisheries, and environmental sciences and policy were in their infancy.

But the early 1970s were a time of revolutionary change in environmental policy in the United States, signaled by passage of the federal Clean Water and Clean Air Acts, Endangered Species Act, Marine Mammal Protection Act and the Magnuson Fisheries Conservation and Management Act. Environmental and wildlife disciplines, including aquatic sciences, thrived and expanded.

Today my UCCE colleagues embody this change in emphasis. Seven county-based Sea Grant Extension Program marine advisors are working on ocean and coastal aquatic issues; numerous county-based advisors have full or partial natural resources or watershed assignments; farm advisors are working on water quality, policy and conservation; and 4-H youth programs involve aquatic education.

UC faculty at most campuses are now working on aquatic topics including anadromous and inland fishes, aquatic nuisance species, water quality, riparian habitat improvement in agriculture, management and conservation of fisheries resources, the San Francisco Bay-Delta ecosystem, water policy, oceanography and aquatic resources economics.

This issue of California Agriculture features two studies on the aquatic ecosystem of the Sacramento-San Joaquin Delta. These papers provide insights useful in guiding the multi-billion-dollar restoration efforts by CALFED (a consortium of state and federal agencies) in California's important delta-estuary system (see pages 104, 110).

Solving California's aquatic problems will require improved understanding of human, biological and physical aquatic ecosystems and the crafting of policies that will sustain the state's productivity and quality of life in the long term.

Continuing and expanding the focus of ANR's multidisciplinary expertise on aquatic issues can have major impacts on these critical problems even with the current difficult state budget climate. Partnerships with UC and CSU campuses, agencies and private-sector groups with expertise and resources devoted to aquatic issues can further enhance ANR's statewide efforts to serve California. 